\title{
Evaluation of Hyperosmotic Sodium Bicarbonate as Adjunct to Ciprofloxacin in the Amelioration of Septicaemia in Salmonella-Induced Bubaline Neonatal Diarrhoea
}

\author{
Ayesha Humayun ${ }^{1}$, Muhammad Arif Zafar ${ }^{1^{*}}$, Arfan Yousaf ${ }^{1}$ and Murtaz-ul-Hasan ${ }^{2}$ \\ ${ }^{1}$ Department of Clinical Studies, Faculty of Veterinary and Animal Sciences, Pir Mehr Ali Shah, Arid Agriculture University, \\ 46300, Rawalpindi, Pakistan \\ ${ }^{2}$ Department of Parasitology and Microbiology, Faculty of Veterinary and Animal Sciences, Pir Mehr Ali Shah, Arid \\ Agriculture University, 46300, Rawalpindi, Pakistan \\ "For correspondence: dr.mazafar@uaar.edu.pk \\ Received 03 December 2020; Accepted 18 January 2021; Published 16 April 2021
}

\begin{abstract}
This study was conducted to evaluate the comparative efficacy of hyperosmotic sodium bicarbonate (HSB $8.4 \%$ ), hypertonic saline (HSS $7.5 \%$ ) and normal saline (NSS 0.9\%) solutions associated with experimentally Salmonella-induced diarrhoea in buffalo neonatal calves. For this purpose, 14-17 days old 18 healthy buffalo calves were reared. After 8-12 h of oral administration of Salmonella broth $\left(6.5 \times 10^{8} \mathrm{CFU}\right)$, diarrhoea was induced successfully. Calves were then randomly divided into three equal groups viz., groups A, B and C and treatment was instituted. Group A received NSS (0.9\%) @ $60 \mathrm{~mL} / \mathrm{kg}$ (body weight) B.W, intravenous (IV) once, group B was administered HSS (7.5\%) @ $5 \mathrm{~mL} / \mathrm{kg}$ B.W, IV once and group C instituted with HSB (8.4\%) @ $5 \mathrm{~mL} / \mathrm{kg}$ B.W, IV once. All three groups were additionally treated with ciprofloxacin @ 7 $\mathrm{mg} / \mathrm{kg}$ B.W, IV bid and flunixin meglumine @ $2 \mathrm{mg} / \mathrm{kg}$ B.W, IV tid. Comparative efficacy of all treatment regimens was assessed through haemodynamic measurements, blood gases determination and serum electrolyte analysis. All parameters were noted at baseline (prior to diarrhoea induction), during neonatal diarrhoea, $\mathrm{t}=3, \mathrm{t}=9, \mathrm{t}=18, \mathrm{t}=36, \mathrm{t}=72, \mathrm{t}=120, \mathrm{t}=168 \mathrm{~h}$ after treatment. The HSB treated calves (group C) revived from diarrhoea quickly (within $9 \mathrm{~h}$ ) and efficiently than NSS (group A) and HSS (group B), exhibited significantly $(P<0.05)$ enhancement. At $\mathrm{t}=18 \mathrm{~h}$, values for central venous partial pressure and systemic vascular resistance were $11.67 \pm 0.7,13.67 \pm 0.61$ and $13.50 \pm 0.56$ and $1180.83 \pm 6.94,1180.83 \pm 6.94$ and 1465.00 \pm 6.76 in groups $\mathrm{A}, \mathrm{B}$ and $\mathrm{C}$, respectively. HSB treated buffalo neonatal calves also showed significant increase in bicarbonate, blood $\mathrm{pH}$, serum electrolytes and partial pressure of venous oxygen. Basis on the results of this study, it was concluded that small-volume administration of HSB profoundly ameliorated deleterious effects of septicaemia and improve haemodynamic stability in Salmonella-induced bubaline neonatal diarrhoea. It provides a practical and economical method to resuscitate dehydrated diarrhoeic calves thus make it convenient to accomplish in on-farm situation. (C) 2021 Friends Science Publishers
\end{abstract}

Keywords: Diarrhoea; Septicaemia; Hypovolemia; HSB; Salmonella; Buffalo calves

\section{Introduction}

Calves are reared as a pre-requisite in cattle industry to meet ever-increasing demand of milk and meat. But, survival of the calves is mainly threatened by different diseases especially at neonatal age. Amongst these diseases, highest incidence of diarrhoea has been reported during first four weeks of life in terms of morbidity and mortality (Foster and Smith 2009; Izzo et al. 2011; Cho et al. 2012; Trefz et al. 2017). Bovine neonatal diarrhoea (BND) associated with Escherichia coli, Salmonella and other gut associated micro-organisms is major cause of death in calves (Icen $e t$ al. 2013). Mortality due to diarrhoea in Pakistan varies from 23.7 to $63.0 \%$ in buffalo calves (Khan and Zaman 2007;
Khan et al. 2009; Zafar at al. 2015).

Successful institution of treatment in diarrhoeic dehydrated calves depends mainly on the management of electrolyte and fluids for the improvement of dehydration and severe acidemia (Foster and Smith 2009). A quick and operative method for fluid administration in severe dehydrated calves would be beneficial that must be a smallvolume, evades the long-time catheterization, reduced labor exhaustive and less time consuming. Furthermost, it must be applicable and practical in the field (Abutarbush et al. 2016). To cope with these requirements, sodium bicarbonate (alkalinizing agent) is used for the treatment of severe acidosis in neonatal calves (Berchtold et al. 2005; Abutarbush et al. 2016) with a theoretical osmolality of

To cite this paper: Humayun A, MA Zafar, A Yousaf, Murtaz-ul-Hasan (2021). Evaluation of hyperosmotic sodium bicarbonate as adjunct to ciprofloxacin in the amelioration of septicaemia in Salmonella-induced bubaline neonatal diarrhoea. Intl J Agric Biol 25:921-928 
2,000 $\mathrm{mOsm} / \mathrm{L}(8.4 \%)$ that alkalinizes the blood compared to metabolizable bases (Berchtold et al. 2005; Constable et al. 2005; Koch and Kaske 2008). It provides quick and effective improvement of severe acid-base abnormalities with severe strong ion acidosis (Coskun et al. 2010). Scanty information is available regarding treatment of BND in buffalo neonatal calves in Pakistan. Therefore, this study was planned to;

- Evaluate the efficacy of rapid intravenous administration of small-volume HSB in buffalo calves suffering from strong ion acidosis and haemodynamic derangements

- Determine the effects of HSB in the amelioration of septicaemia associated with Salmonella-induced BND

\section{Materials and Methods}

\section{Experimental animals}

The experiment was conducted in accordance with protocol approved by the Institutional Animal Ethics Committee, PMAS-Arid Agriculture University, Rawalpindi, Pakistan. For this study, 18 healthy colostrum-fed buffalo neonatal calves of 14-17 days of age with mean weight of $30 \pm 5 \mathrm{~kg}$ were purchased from the local market/farms. These calves were maintained at University Research Farm, Koont, PMAS-Arid Agriculture University, Rawalpindi. The calves were then acclimatized for a period of five days. The calves were fed on milk replacer through bottles with nipple @ 10 percent of body weight per calf per day.

\section{Instrumentation}

The day prior to induction of diarrhoea, the buffalo neonatal calves were sedated through general anaesthesia, xylazine $\mathrm{HCl}\left(\mathrm{Xylaz}^{\circledR}\right.$, Farvet Laboratories, Holland) for aseptic placement of IV catheters. The hair was clipped over the jugular furrow from right and left side and the site was scrubbed through povidone-iodine solution to remove any contamination and placement of IV catheters. An 18-guage catheter was placed in right jugular vein for collection of blood samples and infusion of fluid and other treatment. Left jugular vein was catheterized with Swan-Ganz catheter near scapula-humeral joint. Left carotid artery was exposed surgically and cannulated with a plastic type of catheter and secured with sterile stopcock. After instrumentation, the calves were shifted to movable stalls for $12 \mathrm{~h}$. Baseline values were recorded before induction of Salmonella infection.

\section{Induction of diarrhoea}

After acclimatization period, each calf was drenched with Salmonella broth culture having Salmonella count of $6.5 \times$ $10^{8}$ colony forming unit (CFU) dissolved in $250 \mathrm{~mL}$ of NSS (Fecteau et al. 2003).

\section{Study design}

The calves were then continuously observed after drench of Salmonella broth for onset of diarrhoea. After 8 to $12 \mathrm{~h}$, diarrhoea was successfully induced in all calves. Calves were considered qualified for initiation of treatment when they exhibited $10 \%$ dehydration as determined by skin testing (time $>5$ but $<10$ seconds) and markedly recession of eyeball in orbit (Abutarbush et al. 2016). The calves were then randomly divided into three equal groups viz., A, B and C.

\section{Treatment protocol}

All groups were then allocated with following treatment protocols:

Group A received NSS (0.9\%) @ $60 \mathrm{~mL} / \mathrm{kg}$ B.W once with ciprofloxacin*@ $7 \mathrm{mg} / \mathrm{kg}$ B.W, IV bid and flunixin meglumine** @ $2 \mathrm{mg} / \mathrm{kg} \mathrm{B.W,} \mathrm{IV} \mathrm{tid.}$

Group B was administered with HSS (7.5\%) @ $5 \mathrm{~mL} / \mathrm{kg}$ B.W followed by NSS @ $10 \mathrm{~mL} / \mathrm{kg}$ B.W, IV once along with ciprofloxacin*@ $9 \mathrm{mg} / \mathrm{kg}$ B.W, IV bid and flunixin meglumine** @ $2 \mathrm{mg} / \mathrm{kg}$ B.W, IV tid.

Group C was instituted with HSB*** (8.4\%) @ $5 \mathrm{~mL} / \mathrm{kg}$ B.W followed by NSS @ $10 \mathrm{~mL} / \mathrm{kg}$ B.W, IV at the infusion rate of $1 \mathrm{~mL} / \mathrm{kg} / \mathrm{min}$ for a total treatment time of 5 min once along with ciprofloxacin* @ $7 \mathrm{mg} / \mathrm{kg}$ IV bid and flunixin meglumine**@ $2 \mathrm{mg} / \mathrm{kg}$ B.W, IV tid. Administration of ciprofloxacin and flunixin meglumine was continued for 5 consecutive days in all three groups.

*Novidat $^{\circledR}$, Sami Pharmaceuticals Pvt. Ltd. Karachi, Pakistan

**Tricure ${ }^{\circledR,}$ ICI Animal Health Division, Pakistan

***Natriumhydrogencarbonat, Sigma-Aldrich, Steinheim, Germany.

\section{Measurements and analyses}

Following parameters were evaluated to assess the efficacy of HSB in comparison to NSS and HSS in Salmonellainduced neonatal diarrhoea in buffalo calves:

1. Haemodynamic parameters: Mean arterial pressure (MAP), central venous pressure (CVP) and systemic vascular resistance (SVR) were measured. For that purpose, carotid artery was exposed surgically and cannulated with a plastic type of catheter, sterile stopcock was attached to the hub to measure the MAP (Zafar et al. 2015). CVP was recorded with the use of a Swan-Ganz catheter, jugular vein was catheterized near scapula-humeral joint. All haemodynamic parameters were measured using a "Multiparameter Veterinary Patient Monitor" (Operon Wittlich, Germany) (Berchtold et al. 2005).

2. Determination of blood gases: Partial pressure of venous oxygen $\left(\mathrm{PvO}_{2}\right)$, partial pressure of venous carbon dioxide $\left(\mathrm{PvCO}_{2}\right)$, bicarbonates $\left(\mathrm{HCO}_{3}^{-}\right)$and venous blood $\mathrm{pH}$ were measured through blood gas analyzer. Venous 
blood samples for blood gas analyses were obtained in heparinized tubes. The tubes were placed on ice and processed within 30 minutes of collection. Blood gas analyses was done with the help of Blood Gas and Electrolyte Analyzer (Epoc ${ }^{\circledR}$, Epocal Inc., Canada) at $37^{\circ} \mathrm{C}$ (Zafar et al. 2015).

3. Serum electrolyte: Serum sodium ions concentration $\left(\mathrm{Na}^{+}\right)$, serum potassium ions concentration $\left(\mathrm{K}^{+}\right)$and serum chloride ions concentration $\left(\mathrm{Cl}^{-}\right)$were also measured with the help of Blood Gas and Electrolyte Analyzer (Epoc ${ }^{\circledR}$, Epocal Inc., Canada) at $37^{\circ} \mathrm{C}$ (Zafar et al. 2015).

\section{Measuring intervals}

All aforementioned parameters recorded, at baseline (healthy calves before diarrhoea induction), diarrhoea (during course of diarrhoea in neonatal calves), $\mathrm{t}=3 \mathrm{~h}, \mathrm{t}=9$ $\mathrm{h}, \mathrm{t}=18 \mathrm{~h}, \mathrm{t}=36 \mathrm{~h}, \mathrm{t}=72, \mathrm{t}=120 \mathrm{~h}$ and $\mathrm{t}=168 \mathrm{~h}$ after administration of allocated treatment to each group.

\section{Statistical analyses}

The data obtained was analyzed through completely randomized design (CRD). The significant difference within and between group was analyzed through tukey's test.

\section{Results}

\section{Haemodynamic parameters}

Mean arterial pressure: At baseline, MAP values of all groups differed non-significantly. After induction of diarrhoea, a statistically significant $(P<0.05)$ decrease was observed from the baseline values in all groups. After administration of allocated treatment to diarrhoeic calves, groups B and C displayed a significant $(P<0.05)$ increasing trend over NSS treated calves at each time point and showed significant $(P<0.05)$ differences over group $\mathrm{A}$ at $\mathrm{t}=9$ hand $\mathrm{t}-36 \mathrm{~h}$ (Fig. 1). There was no significant difference observed between groups $\mathrm{B}$ and $\mathrm{C}$, however, better trend was observed in group $\mathrm{C}$.

\section{Central venous pressure}

Values of CVP differed non-significantly between all groups (A, B and C) at baseline. After induction of diarrhoea with Salmonella broth, a significant $(P<0.05)$ decrease was noted from the baseline in all groups. All groups showed a continuous and significant rise up to $t-9 \mathrm{~h}$ followed by a mild decrease in groups $\mathrm{B}$ and $\mathrm{C}$, while a significant $(P<0.05)$ decrease in group A at t-18 h (Fig. 2). Afterwards, groups $\mathrm{B}$ and $\mathrm{C}$ recovered their increasing trend and showed significant $(P<0.05)$ difference over group A throughout study period. Both groups $\mathrm{B}$ and $\mathrm{C}$ recovered baseline values. However, group A failed to regain values of CVP after $\mathrm{t}-18 \mathrm{~h}$ and was unable to recover baseline values withing study period (Fig. 2).

\section{Systemic vascular resistance}

At baseline, values of SVR differed non-significantly in groups $\mathrm{A}, \mathrm{B}$ and $\mathrm{C}$ followed by a significant $(P<0.05)$ decrease after induction of diarrhoea with Salmonella broth. After institution of allocated treatments, group $\mathrm{C}$ showed a rise and differed significantly $(P<0.05)$ at $\mathrm{t}=9 \mathrm{~h}$ which continued up to $\mathrm{t}=36 \mathrm{~h}$ over groups $\mathrm{A}$ and $\mathrm{B}$. Afterwards group $\mathrm{C}$ showed significant difference over group $\mathrm{B}$ at $\mathrm{t}-72$ h. Group A showed significant difference over group B at t$9 \mathrm{~h}$ and $\mathrm{t}-72 \mathrm{~h}$. Whereas group $\mathrm{B}$ showed significant difference over group A at t-36 h (Fig. 3). All groups achieved their baseline values within study period; however, group $\mathrm{C}$ recovered its baseline earlier (at $\mathrm{t}-18 \mathrm{~h}$ ) than its counterparts.

\section{Blood gas analyses}

Partial pressure of venous oxygen: Values of $\mathrm{PvO}_{2}$ of all three groups (A, B and C) differed non-significantly from each other prior to induction of diarrhoea followed by a significant $(P<0.05)$ decrease during diarrhoea. After administration of allocated treatments, all groups showed increasing trend but groups $\mathrm{B}$ and $\mathrm{C}$ showed significant increase $(P<0.05)$ in values of $\mathrm{PvO}_{2}$ than during diarrhoea and showed significant $(P<0.05)$ difference over group A at $\mathrm{t}=18 \mathrm{~h}$. This trend was maintained by groups $\mathrm{B}$ and $\mathrm{C}$ and it showed significant $(P<0.05)$ difference over group A throughout rest of the study period. Baseline values were achieved by group $\mathrm{C}$ at $\mathrm{t}=168 \mathrm{~h}$ (Fig. 4). Whereas group B almost achieved basal values at $\mathrm{t}=168 \mathrm{~h}$, while group $\mathrm{A}$ failed to recover baseline values till end of study period (Fig. 4).

\section{Partial pressure of venous carbon dioxide}

At baseline, values of $\mathrm{PvCO}_{2}$ were non-significantly differed between three groups prior to the induction of Salmonella infection. Values of $\mathrm{PvCO}_{2}$ increased significantly $(P<0.05)$ during diarrhoea. After administration of specific treatment to the calves, all groups showed decreasing trend after $\mathrm{t}-3 \mathrm{~h}$. At $\mathrm{t}-18 \mathrm{~h}$, group $\mathrm{C}$ showed better decreasing trend and showed significant $(P<$ 0.05 ) difference over other groups (Fig. 5). Recovery trend was almost similar in groups A and B up to t-72 h. At t-120 h, group B showed significant $(P<0.05)$ difference over group $\mathrm{A}$. Baseline values were recovered by groups $\mathrm{B}$ and $\mathrm{C}$ at $\mathrm{t}-120 \mathrm{~h}$ whereas group A was unable to achieve its basal values (Fig. 5).

\section{Blood pH}

A non-significantly difference was noted in the values of Blood pH prior to Salmonella infection between all groups. There was a non-significant decrease in values of blood $\mathrm{pH}$ in all groups during diarrhoea. After institution of allocated treatments, all groups showed increasing trend. However, 


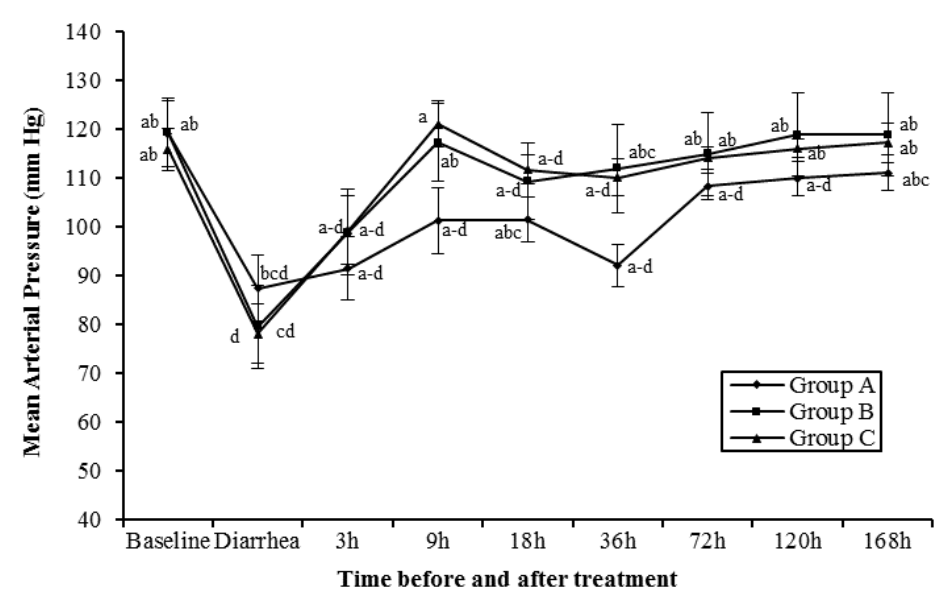

Fig. 1: Mean arterial pressure (mm Hg) in Salmonella-induced buffalo calf neonatal diarrhoea, in response to treatments with IV administration of NSS (group A), HSS (group B) and HSB (group C) along with ciprofloxacin and flunixin meglumine

*Indicates statistically significant $(\mathrm{P}<0.05)$ difference of that group over the others which do not contain it. Means \pm SE sharing similar letter within each group are non-significant

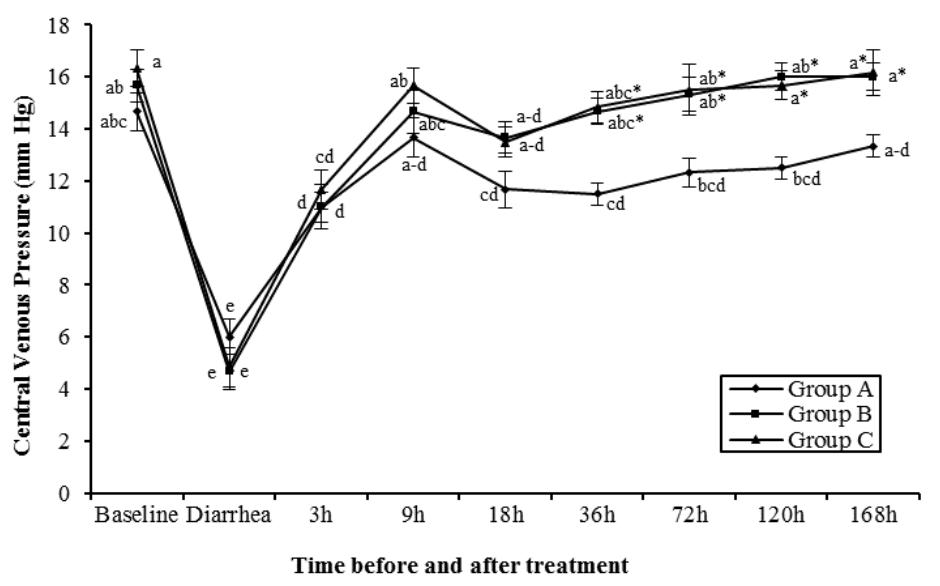

Fig. 2: Central venous pressure (mm Hg) in Salmonella-induced buffalo calf neonatal diarrhoea, in response to treatments with IV administration of NSS (group A), HSS (group B) and HSB (group C) along with ciprofloxacin and flunixin meglumine

*Indicates statistically significant $(P<0.05)$ difference of that group over the others which do not contain it. Means \pm SE sharing similar letter within each group are non-significant

better recovery trend was observed in calves of group $\mathrm{C}$ treated with HSB. Basal values of blood $\mathrm{pH}$ were achieved by groups $\mathrm{B}$ and $\mathrm{C}$ at the end of study. Whereas, blood $\mathrm{pH}$ values were near to baseline in group A at t-168 h (Fig. 6).

\section{Bicarbonates}

At baseline, values of bicarbonates were non-significantly differed between all groups. A significant decrease was noted during Salmonella-induced diarrhoea. After institution of treatment, a constant increasing trend was observed in groups $\mathrm{A}$ and $\mathrm{C}$, while group $\mathrm{B}$ showed fluctuance in its trend. There was no significant difference between all groups at any interval, however, group $\mathrm{C}$ showed better recovery trend and achieved their basal values at the end of study whereas values of bicarbonates were near to baseline in groups A and B (Fig. 7).

\section{Serum electrolyte analyses}

Sodium ions concentration: At baseline, values of serum sodium ions concentration of all groups were nonsignificantly differed. A significant decrease was observed during diarrhoea. After administration of allotted treatments, all groups showed recovery but trend was much better in groups B and $\mathrm{C}$. These both groups showed significant $(P<$ $0.05)$ difference over group A. Groups $\mathrm{B}$ and $\mathrm{C}$ achieved their basal values at $\mathrm{t}-18 \mathrm{~h}$, while group A recovered its basal values at $\mathrm{t}-36 \mathrm{~h}$ followed by a non-significant drop (Table 1).

\section{Serum potassium concentration}

Baseline values of serum potassium ions concentration was non-significant among all groups followed by a significant 


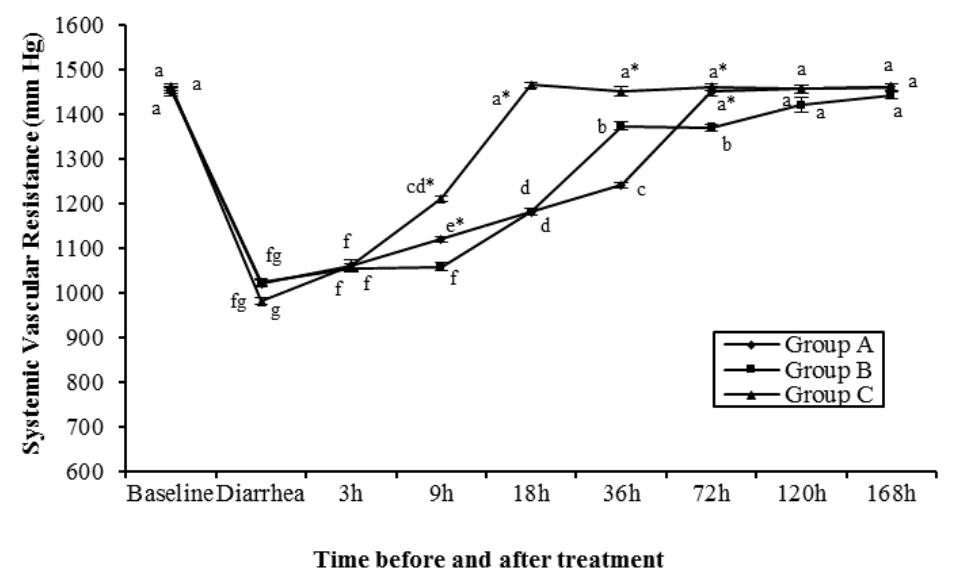

Fig. 3: Systemic vascular resistance $(\mathrm{mm} \mathrm{Hg})$ in Salmonella-induced buffalo calf neonatal diarrhoea, in response to treatments with IV administration of NSS (group A), HSS (group B) and HSB (group C) along with ciprofloxacin and flunixin meglumine *Indicates statistically significant $(\mathrm{P}<0.05)$ difference of that group over the others which do not contain it. Means \pm SE sharing similar letter within each group are non-significant

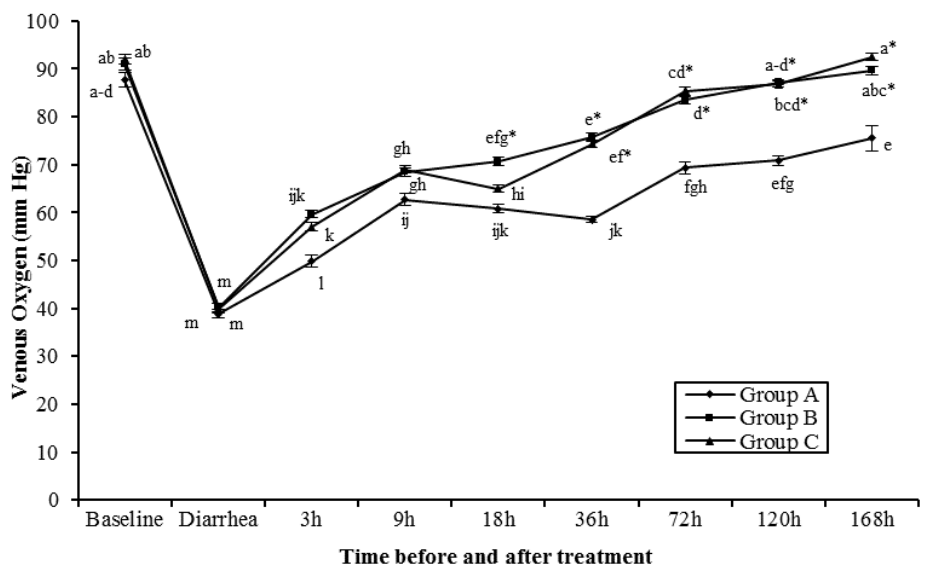

Fig. 4: Partial pressure of venous oxygen $(\mathrm{mm} \mathrm{Hg})$ in Salmonella-induced buffalo calf neonatal diarrhoea, in response to treatments with IV administration of NSS (group A), HSS (group B) and HSB (group C) along with ciprofloxacin and flunixin meglumine *Indicates statistically significant $(\mathrm{P}<0.05)$ difference of that group over the others which do not contain it. Means $\pm \mathrm{SE}$ sharing similar letter within each group are non-significant

decrease during Salmonella infection. After administration of allotted treatment protocols, slow recovery trend was observed in group A, while this trend was better in groups B and C. Group C recovered its basal values at $\mathrm{t}-120 \mathrm{~h}$ whereas group B achieved its baseline values at $\mathrm{t}-168 \mathrm{~h}$. Group A was unable to achieve its basal values (Table 1). Therefore, group $\mathrm{C}$ showed overall better recovery during study period.

\section{Serum chloride concentration}

During the course of diarrhoea, there was a decrease in serum chloride in the neonatal calves of all groups (A, B and C). After administration of allocated treatment protocols, all groups showed recovery trend and there was no significant difference between them. However, recovery trend was better in group $\mathrm{C}$ and it achieved its baseline values within study period. Whereas groups A and B were near to the baseline (Table 1).

\section{Discussion}

Diarrhoea is one of the major devastating conditions of neonatal calves. It attributed a huge economic loss to calf industry through a high mortality rate (Khan et al. 2009; Coskun et al. 2010; Smith and Berchtold 2014; Zafar et al. 2015). In Pakistan, mortality due to neonatal diarrhoea in buffalo calves is as high as $38.08 \%$ (Khan et al. 2009). Salmonella plays a major role in increased mortality during neonatal period especially at the age of third week. Salmonella act on intestine after its adherence to the mucosal membrane. After adherence, it proliferates in lumen of the intestine and secretes fatal enterotoxins which stimulate secretion of chloride ions which draws water in to 


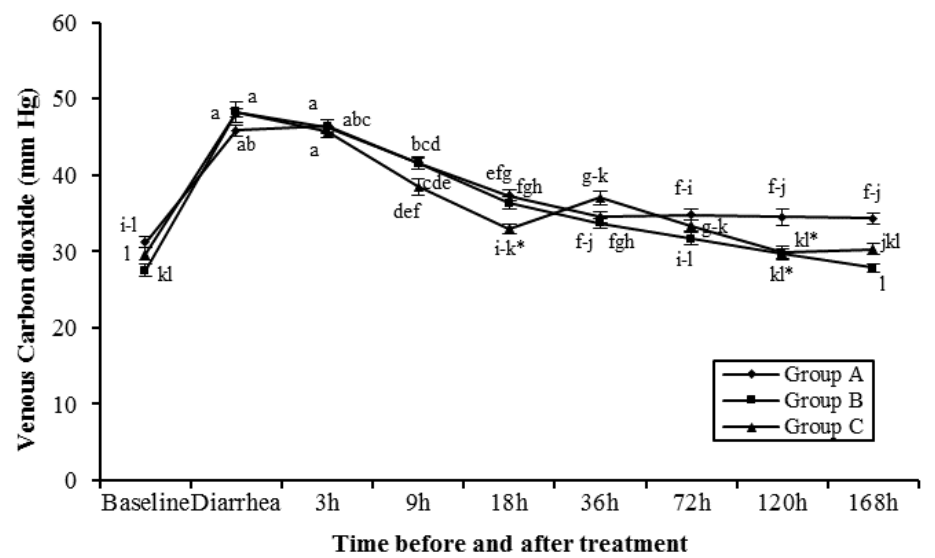

Fig. 5: Partial pressure of venous carbon dioxide $(\mathrm{mm} \mathrm{Hg})$ in Salmonella-induced buffalo calf neonatal diarrhoea, in response to treatments with IV administration of NSS (group A), HSS (group B) and HSB (group C) along with ciprofloxacin and flunixin meglumine *Indicates statistically significant $(\mathrm{P}<0.05)$ difference of that group over the others which do not contain it. Means \pm SE sharing similar letter within each group are non-significant

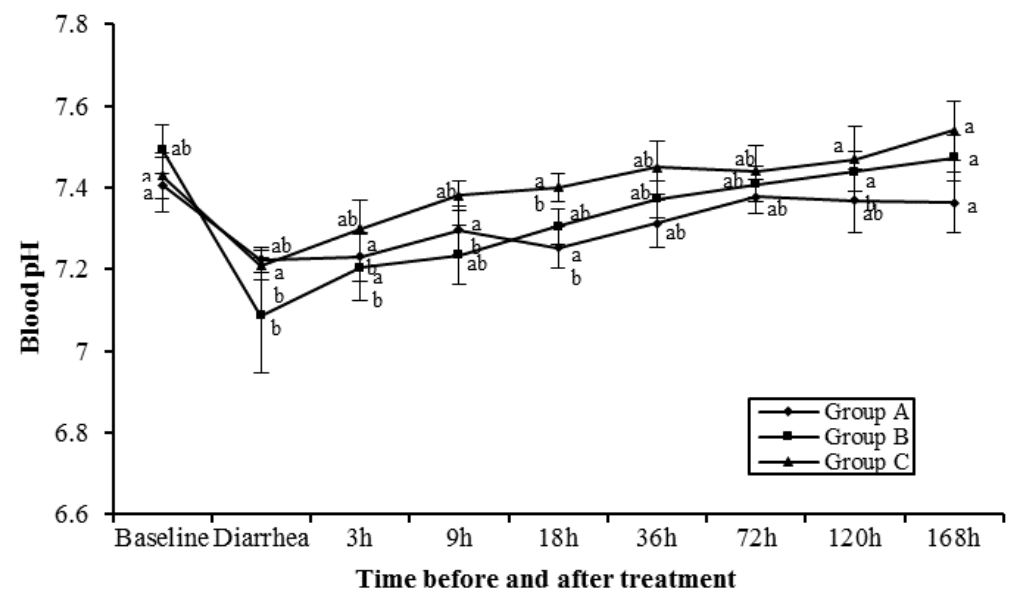

Fig. 6: Blood pH in Salmonella-induced buffalo calf neonatal diarrhoea, in response to treatments with IV administration of NSS (group A), HSS (group B) and HSB (group C) along with ciprofloxacin and flunixin meglumine

*Indicates statistically significant $(\mathrm{P}<0.05)$ difference of that group over the others which do not contain it. Means \pm SE sharing similar letter within each group are non-significant

the lumen of intestine (Foster and Smith 2009; Smith and Berchtold 2014). Excessive fluid secretion causes principal sign of diarrhoea eventually leads to septicaemia and dehydration lead by hypovolaemia. Dehydration and hypovolaemia cause excessive loss of electrolytes and acidbase imbalance (Constable et al. 2005). This study was conducted for the evaluation of the HSB in combination with ciprofloxacin and flunixin meglumine in buffalo neonatal calves. Diarrhoea was introduced by the administration of Salmonella through oral route. A dehydration status of $10 \%$, decrease in sodium, potassium and chloride ions concentration, blood $\mathrm{pH}$, bicarbonates, $\mathrm{PvO}_{2}$ and increased $\mathrm{PvCO}_{2}$ were noted during Salmonellainduced buffalo neonatal diarrhoea.

Diarrhoea causes severe dehydration in neonates, which results decrease in volume of extracellular fluid which lead to depletion in plasma volume. The purpose of the treatment is to reinstate the plasma volume through intravenous fluid administration. A rapid increase in plasma volume was observed after administration of HSS and HSB due to abrupt rise in serum osmolarity from intracellular compartment (Berchtold et al. 2005; Silva and Figueiredo 2005; Flores et al. 2006; Trefz et al. 2017). In this study, haemodynamic parameters were significantly increased immediately after administration of HSB especially MAP and CVP. Systemic vascular resistance was also improved significantly by HSB infusion in buffalo calves of group C which was severely affected during neonatal diarrhoea. Most likely, it is due to increased preload and plasma expansion (Bleul et al. 2007; Coskun et al. 2010).

Blood gases are good indicators of acid/base imbalance and provide guide to develop treatment regimen 
Table 1: Results of serum electrolytes in Salmonella-induced buffalo calf neonatal diarrhoea, in response to treatments with IV administration of NSS (group A), HSS (group B) and HSB (group C) along with ciprofloxacin and flunixin meglumine

\begin{tabular}{|c|c|c|c|c|c|c|c|c|c|c|}
\hline \multirow[t]{2}{*}{ Variables } & \multirow[t]{2}{*}{ Groups } & \multicolumn{9}{|c|}{ Time after treatment } \\
\hline & & Baseline & Diarrhoea & $\mathrm{t}=3 \mathrm{~h}$ & $\mathrm{t}=9 \mathrm{~h}$ & $\mathrm{t}=18 \mathrm{~h}$ & $\mathrm{t}=36 \mathrm{~h}$ & $\mathrm{t}=72 \mathrm{~h}$ & $\mathrm{t}=120 \mathrm{~h}$ & $\mathrm{t}=168 \mathrm{~h}$ \\
\hline \multirow{3}{*}{$\begin{array}{l}\text { Sodium } \\
(\mathrm{mmol} / \mathrm{L})\end{array}$} & Group A & $140.17 \pm 2.90^{\mathrm{a}-\mathrm{f}}$ & $117.33 \pm 2.51^{\text {hi }}$ & $119.17 \pm 2.81^{\text {hi }}$ & $125.33 \pm 1.89^{\text {ghi }}$ & $134.17 \pm 2.21^{\mathrm{d}-\mathrm{g}}$ & $140.50 \pm 2.06^{\mathrm{a}-\mathrm{f}}$ & $139.83 \pm 2.89^{a-f}$ & $138.67 \pm 1.31^{\mathrm{a}-\mathrm{f}}$ & $137.33 \pm 2.56^{\mathrm{b}-\mathrm{g}}$ \\
\hline & Group B & $138.17 \pm 3.60^{\mathrm{b}-\mathrm{f}}$ & $115.50 \pm 2.58^{i}$ & $129.17 \pm 2.68^{\text {fgh }}$ & $135.33 \pm 2.87^{\mathrm{c}-\mathrm{g}}$ & $146.17 \pm 1.74^{a-d}$ & $149.00 \pm 2.78^{\mathrm{ab}}$ & $145.17 \pm 1.30^{\mathrm{a}-\mathrm{d}}$ & $140.83 \pm 1.82^{\mathrm{a}-\mathrm{f}}$ & $141.33 \pm 2.42^{\mathrm{a}-\mathrm{f}}$ \\
\hline & Group & $141.83 \pm 2.66^{\mathrm{a}-\mathrm{e}}$ & $116.33 \pm 2.04^{i}$ & $132.50 \pm 2.49^{\mathrm{efg}}$ & $139.83 \pm 1.38^{\mathrm{a}-\mathrm{f}}$ & $148.17 \pm 1.99^{\mathrm{ab}}$ & $150.67 \pm 2.76^{\mathrm{a}}$ & $146.83 \pm 1.35^{\mathrm{abc}}$ & $143.83 \pm 1.94^{\mathrm{a}-\mathrm{e}}$ & $142.83 \pm 2.64^{\text {a-e }}$ \\
\hline \multirow{3}{*}{$\begin{array}{l}\text { Potassium } \\
(\mathrm{mmol} / \mathrm{L})\end{array}$} & Group A & $5.22 \pm 0.16^{\mathrm{a}}$ & $2.87 \pm 0.11^{\mathrm{i}}$ & $3.52 \pm 0.16^{\text {ghi }}$ & $3.93 \pm 0.14^{\mathrm{e}-\mathrm{h}}$ & $3.97 \pm 0.14^{\mathrm{d}-\mathrm{h}}$ & $4.17 \pm 0.10^{\mathrm{c}-\mathrm{h}}$ & $4.25 \pm 0.19^{\mathrm{b}-\mathrm{g}}$ & $4.32 \pm 0.12^{b-\mathrm{g}}$ & $4.72 \pm 0.14^{\mathrm{a}-\mathrm{e}}$ \\
\hline & Group B & $5.08 \pm 0.19^{\mathrm{ab}}$ & $3.35 \pm 0.20^{\mathrm{hi}}$ & $4.48 \pm 0.11^{\mathrm{a}-\mathrm{e}}$ & $4.78 \pm 0.13^{\mathrm{a}-\mathrm{d}}$ & $4.92 \pm 0.16^{\mathrm{abc}}$ & $4.65 \pm 0.17^{\mathrm{a}-\mathrm{e}}$ & $4.65 \pm 0.17^{\mathrm{a}-\mathrm{e}}$ & $4.82 \pm 0.15^{\mathrm{abc}}$ & $4.98 \pm 0.13^{\mathrm{abc}}$ \\
\hline & Group C & $5.27 \pm 0.19^{\mathrm{a}}$ & $3.62 \pm 0.23^{f-i}$ & $4.80 \pm 0.15^{\mathrm{a}-\mathrm{d}}$ & $4.45 \pm 0.17^{\mathrm{a}-\mathrm{f}}$ & $4.63 \pm 0.19^{\mathrm{a}-\mathrm{e}}$ & $4.87 \pm 0.17^{\mathrm{abc}}$ & $4.85 \pm 0.15^{\mathrm{abc}}$ & $5.20 \pm 0.17^{\mathrm{a}}$ & $5.18 \pm 0.16^{\mathrm{a}}$ \\
\hline \multirow{3}{*}{$\begin{array}{l}\text { Chloride } \\
(\mathrm{mmol} / \mathrm{L})\end{array}$} & Group A & $98.33 \pm 2.60^{\mathrm{abc}}$ & $77.67 \pm 1.33^{\mathrm{ij}}$ & $81.17 \pm 2.52^{\mathrm{hij}}$ & $85.67 \pm 1.96^{\mathrm{e}-\mathrm{i}}$ & $88.17 \pm 2.39^{\mathrm{d}-\mathrm{h}}$ & $92.17 \pm 2.14^{\mathrm{a}-\mathrm{g}}$ & $95.17 \pm 2.21^{\mathrm{a}-\mathrm{f}}$ & $95.67 \pm 2.82^{\mathrm{a}-\mathrm{e}}$ & $95.83 \pm 2.81^{\mathrm{a}-\mathrm{d}}$ \\
\hline & Group B & $99.17 \pm 1.87^{\mathrm{ab}}$ & $75.00 \pm 1.26^{\mathrm{j}}$ & $83.50 \pm 2.26^{\mathrm{g}-\mathrm{j}}$ & $85.17 \pm 1.83^{\mathrm{f}-\mathrm{i}}$ & $89.00 \pm 1.48^{\mathrm{c}-\mathrm{h}}$ & $89.33 \pm 1.76^{\mathrm{b}-\mathrm{h}}$ & $92.00 \pm 1.75^{\mathrm{a}-\mathrm{g}}$ & $93.33 \pm 2.46^{\mathrm{a}-\mathrm{g}}$ & $97.33 \pm 1.54^{\mathrm{a}-\mathrm{d}}$ \\
\hline & Group C & $101.17 \pm 1.19^{\mathrm{a}}$ & $75.67 \pm 1.45^{\mathrm{ij}}$ & $89.00 \pm 1.32^{\mathrm{c}-\mathrm{h}}$ & $90.33 \pm 1.17^{\mathrm{b}-\mathrm{h}}$ & $91.67 \pm 1.56^{\mathrm{a}-\mathrm{g}}$ & $91.83 \pm 1.89^{\mathrm{a}-\mathrm{g}}$ & $93.67 \pm 1.91^{\mathrm{a}-\mathrm{f}}$ & $96.17 \pm 1.60^{a-d}$ & $101.50 \pm 1.28^{\mathrm{a}}$ \\
\hline
\end{tabular}

Group A received NSS (0.9\%) once along with ciprofloxacin and flunixin meglumine; group B was administered with HSS (7.5\%) once along with ciprofloxacin flunixin meglumine and group C was instituted with HSB (8.4\%) once along with ciprofloxacin and flunixin meglumine

*Indicates statistically significant $(P<0.05)$ difference of that group over the others which does not contain it. Means \pm SE sharing similar letter within each group are non-significant

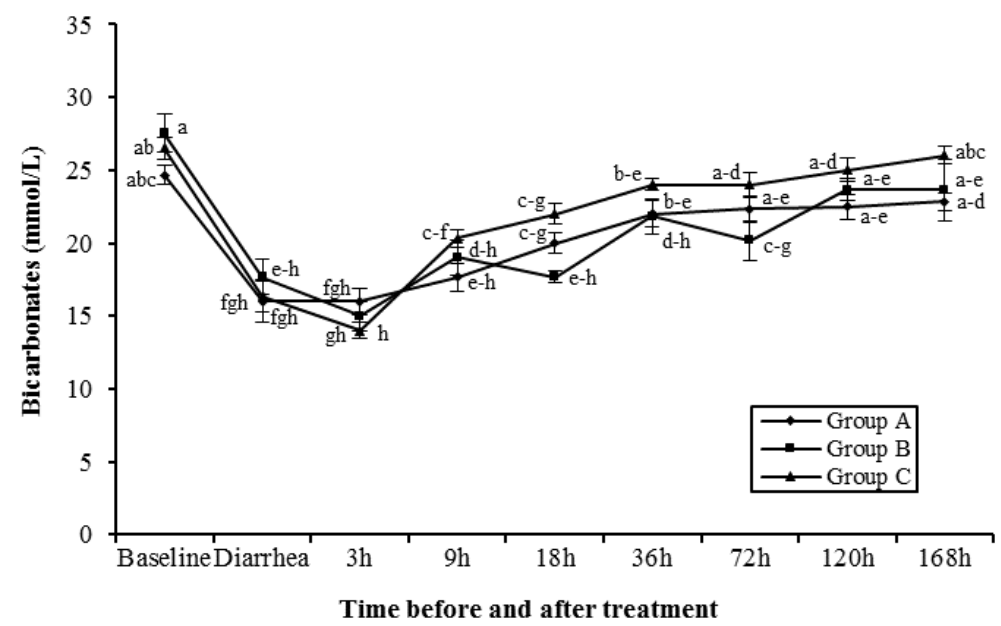

Fig. 7: Bicarbonates in in Salmonella-induced buffalo calf neonatal diarrhoea, in response to treatments with IV administration of NSS (group A), HSS (group B) and HSB (group C) along with ciprofloxacin and flunixin meglumine

*Indicates statistically significant $(P<0.05)$ difference of that group over the others which does not contain it. Means \pm SE sharing similar letter within each group are non-significant

for resuscitation of neonatal calves suffering from acidemia. In this study, a decreased value of $\mathrm{PvO}_{2}$ and increased in $\mathrm{PvCO}_{2}$ values were observed. Similarly, there was decrease in values of bicarbonates and blood $\mathrm{pH}$ during diarrhoea in calves clearly indicates that calves were suffering with metabolic acidosis. Bolus administration of $8.4 \% \mathrm{NaHCO}_{3}$ solution resulted in increased blood $\mathrm{pH}$ and bicarbonates concentration (Koch and Kaske 2008). These results were correlated with the studies of Coskun et al. (2010) who compared two different IV concentrations of HSB i.e., $\left(1.3 \%\right.$ and $\left.8.4 \% \mathrm{NaHCO}_{3}\right)$ and concluded that $8.4 \% \mathrm{NaHCO}_{3}$ solution showed a marked increase in bicarbonates within an hour. Bolus administration of HSB was effective at increasing blood $\mathrm{pH}$ and decreasing $\mathrm{CO}_{2}$ pressure in neonatal buffalo calves suffering from hypoxia and metabolic acidosis (Berchtold et al. 2005; Hasanpour et al. 2009; Leal et al. 2012). Hypoxemia might be due to oedema in endothelial cell of capillary venules endothelium results in the obstruction of blood flow and oxygen transport reduction (Constable et al. 1996; Oliveira et al. 2002; Berchtold et al. 2005; Koch and Kaske 2008; Leal et al. 2012). Hyperosmotic sodium bicarbonate is a hyperosmolar solution and it is hypothesized that it is capable to induce shrinkage of endothelial cell which results in improvement of tissue perfusion and transport of oxygen to the tissues (Suzuki et al. 2002; Oliveira et al. 2002).

Hyponatraemia and hypochloraemia was detected in diarrhoeic calves in several studies (Berchtold et al. 2005; Naylor 2009; Zafar et al. 2015). In this study, decrease in sodium, potassium and chloride ions concentration was observed. Intravenous bolus administration of HSB caused an instantaneous increase in serum sodium, potassium and chloride concentration (Berchtold et al. 2005; Flores et al. 2006; Koch and Kaske 2008; Coskun et al. 2010; Trefz et al. 2017). The peak value of serum sodium that was observed in current study after IV bolus administration of HSB was $150.67 \pm 2.76 \mathrm{mmol} / \mathrm{L}$ in buffalo neonates. However, the use of HSB is conflicting in chronic hyponatraemic patients as it develops the neurological problems (Dibartola 2000). However, no change in the attitude and overall behaviour of the buffalo calves was 
detected after IV administration of HSB in this study.

\section{Conclusion}

Bolus IV administration of small-volume of HSB (8.4\% $\mathrm{NaHCO}_{3}$ ) along with ciprofloxacin and flunixin profoundly ameliorated deleterious effects of septicaemia and has sound physiological basis to improve haemodynamic parameters in Salmonella-induced diarrhoea in buffalo calves. Smallvolume of HSB provides an effective and rapid recovery to calves suffering from strong-ion acidosis and also improves oxygen delivery. Most of all, it provides an economical and practical approach for resuscitation of severely dehydrated diarrhoeic calves thus make it convenient to accomplish in on-farm situation.

\section{Author Contributions}

Ayesha Humayun conducted the trial and managed the data. Muhammad Arif Zafar presented the idea and planned whole study. He also monitored and helped in conducting the study. Arfan Yousaf helped to manage the animals for trial and faccilitated whole study on University Research Farm, Koont. Murtaz-ul-Hasan helped in rearing the animals, managed the data, and facilitated laboratoy work regarding microbiology.

\section{Conflicts of Interest}

All other authors declare no conflicts of interest

\section{Data Availability}

Data presented in this study are available on fair request to the corresponding author.

\section{Ethics Approval}

The experiments were carried out in accordance with the guidelines issued by the Ethical Committee of Pir Mehr Ali Shah, Arid Agriculture University, Rawalpindi, Pakistan.

\section{References}

Abutarbush SM (2016). Veterinary medicine - a textbook of diseases of cattle, horses, sheep, pigs and goats. Can Vet J 51:541

Berchtold JF, PD Constable, GW Smith, M Mathur, DE Morin, WJ Tranquilli (2005). Effects of intravenous hyperosmotic sodium bicarbonate on arterial and cerebrospinal fluid acid-base status and cardiovascular function in calves with experimentally induced respiratory and strong ion acidosis. $J$ Vet Intl Med 19:240-251

Bleul UT, SC Schwantag, WK Kahn (2007). Effects of hypertonic sodium bicarbonate solution on electrolyte concentrations and enzyme activities in newborn calves with respiratory and metabolic acidosis. Amer J Vet Res 68:850-857

Cho YI, D Sun, V Cooper, G Dewell, K Schwartz, KJ Yoon (2012). Evaluation of a commercial rapid test kit for detecting bovine enteric pathogens in feces. J Vet Diagn Invest 24:559-562
Constable PD, HR Stampfli, HR Navetat, J Berchtold, F Schelcher(2005). Use of a quantitative strong ion approach to determine the mechanism for acid-base abnormalities in calves with and without diarrhoea. J Vet Intl Med 19:581-589

Constable PD, HM Gohar, DE Morin, JC Thurmon (1996). Use of hypertonic saline-dextran solution to resuscitate hypovolemic calves with diarrhoea. Amer J Vet Res 1:97-104

Coskun A, I Sen, H Guzelbektes, M Ok, K Turgut, S Canikli (2010). Comparison of the effects of intravenous administration of isotonic and hypertonic sodium bicarbonate solutions on venous acid-base status in dehydrated calves with strong ion acidosis. J Amer Vet Med Assoc 236:1098-1103

Dibartola SP (2012). Disorders of sodium and water: Hypernatremia and hyponatremia, Chapter 3, pp:45-79. In: Fluid Therapy in Small Animal Practice, $4^{\text {th }}$ edn. Saunders, St. Louis, Missouri, USA

Fecteau M, JK House, SF Kotarski, NS Tankersley, MM Ontiveros, CR Alcantar, BP Smith (2003). Efficacy of ceftiofur for treatment of experimental salmonellosis in neonatal calves. Amer $J$ Vet Res 64:918-925

Flores RV, CA Souza, NM Ocarino, VA Gheller, MJ Lopes, MS Palhares, R Serakides (2006). Hypertonic and isotonic saline solutions in dehydration therapy in neonatal calves: comparison of clinical profile and serum and urinary concentration of electrolytes. Compar Clin Pathol 15:131-142

Foster DM, GW Smith (2009). Pathophysiology of diarrhoea in calves. Vet Clin Food Anim 25:13-36

Hasanpour A, TB Amougli, SAP Rezaie, M Imandar (2009). Evaluating the effects of administrating hypertonic and isotonic saline solutions on clinical improvement, serum electrolyte concentration and renal function of calves affected by diarrhoea. Vet Clin Pathol 3:579-590

Icen H, NB Arserim, N Isik, C Ozkan, A Kaya (2013). Prevalence of four enter pathogens with immunochromatographic rapid test in the feces of diarrheic calves in East and Southeast of Turkey. Pak Vet J 33:496-499

Izzo MM, PD Kirkland, VL Mohler, AA Gunn, JK House (2011). Prevalence of major enteric pathogens in Australian dairy calves with diarrhoea. Aust Vet J 89:167-173

Khan A, T Zaman (2007). Effects of rehydration solution on hematological and biochemical parameters in induced buffalo neonatal calf diarrhoea. Ital J Anim Sci 6:957-960

Khan JA, MS Khan, MA Khan, M Avais, A Maqbool, M Salman, ZU Rehman (2009). Epidemiology of major bacterial and viral causes of diarrhoea in buffalo calves in three districts of the Punjab province of Pakistan. J Zool Suppl Ser 9:187-193

Koch A, M Kaske (2008). Clinical efficacy of intravenous hypertonic saline solution or hypertonic bicarbonate solution in the treatment of in appetent calves with neonatal diarrhoea. $J$ Vet Intl Med 22:202-211

Leal M, S Fialho, FC Cyrillo, HG Bertagnon, EL Ortolani, FJ Benesi (2012). Intravenous Hypertonic Saline Solution (7.5\%) and Oral Electrolytes to Treat of Calves with Noninfectious Diarrhoea and Metabolic Acidosis. J Vet Intl Med 26:1042-1050

Naylor JM (2009). Calf neonatal diarrhoea. Food Anim Prac 2009:70-77

Oliveira RP, I Vealsco, FG Soriano, G Friedman (2002). Clinical Review: Hypertonic saline resuscitation in sepsis. Crit Care 6:418-423

Silva MRE, LFPD Figueiredo (2005). Small volume hypertonic resuscitation of circulatory shock. Clinics 60:159-172

Smith GW, J Berchtold (2014). Fluid therapy in calves. Vet Clin Food Anim 30:409-427

Suzuki K, I Abe, S Iwabuchi, S Tsumagari, T Matsumoto, R Asano (2002). Evaluation of isotonic sodium bicarbonate solution for alkalizing effects in conscious calves. $J$ Vet Med Sci 64:699-703

Trefz FM, PD Constable, I Lorenz (2017). Effects of Intravenous small volume hypertonic sodium bicarbonate, sodium chloride and glucose solutions in decreasing plasma potassium concentration in hyperkalemic neonatal calves with diarrhoea. $J$ Vet Intl Med 31:907-921

Zafar MA, G Muhammad, Z Iqbal, A Yousaf, A Riaz (2015). Evaluation of relative resuscitative effects of hypertonic and isotonic saline solutions as an adjunct to ceftiofur $\mathrm{HCl}$ in bovine neonatal diarrhoea associated with Escherichia coli. Intl J Agric Biol 17:953-960 